\title{
Essential oils composition of Pinus peuce Griseb. (Pinaceae) growing on Pelister Mtn., Republic of Macedonia
}

\author{
Marija Karapandzova*, Gjose Stefkov, Svetlana Kulevanova \\ Institute of Pharmacognosy, Faculty of Pharmacy, University "Ss. Cyril and Methodius", Skopje, Macedonia
}

Received: May 2011; Accepted: June 2011

\begin{abstract}
The composition of essential oils obtained by hydrodistillation from needles, from branches without needles and from branches with needles of Pinus peuce Griseb. (Pinaceae) from Pelister Mtn. (R. Macedonia) was analyzed by GC/FID/MS. One hundred and seven components (40 monoterpenes, 37 sesquiterpenes, 9 diterpenes and 21 other components - aliphatic and cyclic hydrocarbons; aliphatic alcohols, aldehydes, and acids; phenols and other oxygenated benzene derivates) were identified. The most abundant constituents were terpene hydrocarbons, encompassing the monoterpenes: $\alpha$-pinene, $\beta$-pinene, limonene $+\beta$-phellandrene and bornyl acetate and the sesquiterpenes: trans (E)-caryophyllene and germacrene D.
\end{abstract}

Key words: Pinus peuce, Macedonian pine, essential oil composition, GC/FID/MS. Natural park Pelister, locus classicus, R. Macedonia.

\section{Introduction}

Pinus peuce Griseb. (Pinaceae), commonly called Macedonian pine or Balkan pine is an endemic conifer tree inhabiting the southern and western parts of the territory of R. Macedonia. This conifer is autothonus to the Baba Mountain (Pelister), Nidze and Shara Mountain. It can be also found in Bulgaria, Albania, Serbia and Greece, growing typically at $1000-2200 \mathrm{~m}$ altitude. It is a member of the white or soft pine group (subgenus Strobus, section Strobus, subsection Strobi), and thus differes from the other pine species (P. mugo, P. nigra and P. sylvestris) growing in R. Macedonia, that belong to the yellow or hard pine group (subgenus Pinus, section Pinus, subsection Pinus).

For the first time, Pinus peuce was described on Baba Mountain (Pelister) in 1839 by Grisebach, thus this location is locus classicus for this species.

In folk medicine, pine needle essential oils are mainly used for the treatment of respiratory infections accompanied by cough, bronchitis, bronchial asthma, emphysema, tracheitis, sinusitis, laryngitis, pharyngitis, tonsillitis

\footnotetext{
Marija Karapandzova@ff.ukim.edu.mk;

marijakarapandzova@yahoo.com
}

and influenza (Dervendzi, 1992). Data from recent scientific literature suggest an increased interest in studying the composition of the essential oil isolated from different pine species as well as biological activity. Generally, monoterpenes and sesquiterpenes are dominant components of pine needle essential oils (Dob, 2007; Menkovic, 1993; Nikolic, 2007; Dob, 2006; Pagula, 2006; Dormont, 1998; Roussis, 1994; Yong-Suk, 2005; Oluwadayo, 2008, Barnola, 2000). It is important to notice that these essential oils have antimicrobial (Oluwadayo, 2008; Yong-Suk, 2005; Sacchetti, 2005), antifungal and antioxidant activity (Guri, 2006; Limei, 2008; Pinelo, 2004; Jerez, 2005; Jerez, 2006; Guolcin, 2003; Sacchetti, 2005). Because of their characteristic odor, pine essential oils are also appreciated in the cosmetic and perfume manufacture. There are several registered pharmaceuticals such as Pinimenthol ${ }^{\circledR}$ ointment which contains pine needle essential oil and is particularly suitable for the treatment for upper respiratory tract infections both in adolescents and adults (Kamin, 2007).

Nowdays, there is uprising trend of consumption of value added natural products complying different standards as Sustainable, Organic/Biological, Fare Wild etc. The populations of P.peuce in the National Park (NP) Pelister have a great resource potential and sustainable use of these natu- 
ral resources can have a significant socio-economic impact on local community. In this direction, assessment of the essential oil of P.peuce would greatly contribute in its value added portfolio.

Up to present, there are no evident data about essential oil composition of Pinus peuce population growing on NP Pelister (locus classicus) neither from any locality of the territory of R. Macedonia. On a subject of all previously mentioned, the aim to this study was to obtain data for the yield and composition of the essential oils isolated from needles, from branches without needles and from branches with needles of Pinus peuce from NP Pelister.

\section{Material and methods}

\section{Plant material}

Only terminal, up to three years old branches were collected in July, 2008 and 2009, in the NP Pelister on 4 different altitudes (1208 m.a.s.1., 1723 m.a.s.1., 1943 m.a.s.l. and 2042 m.a.s.1.). Plant identity was verified as Pinus peuce Grisebach and voucher specimens (No2008/Pp, No2009/ $\mathrm{Pp}$ ) were deposited at the Herbarium at the Department of Pharmaceutical Botany, Institute of Pharmacognosy, Faculty of Pharmacy, Skopje. Plant material was dried at room temperature and on draft for two weeks. The needles were separated from the branches just before the hydrodestillation and were properly minced.

\section{Essential oil isolation}

Essential oil isolation from plant material was made by hydrodestillation in all-glass Clevenger apparatus $(\mathrm{Ph}$. Eur 7). For that purpose, $20 \mathrm{~g}$ of plant material (needles, branches without needles and branches with needles) was distilled for 4 hours. After isolation, anhydrous sodium sulfate was added to remove residual water and to dry essential oil.

For GC/FID/MS analysis, the essential oil was dissolved in xylene $(1: 1000 \mathrm{v} / \mathrm{v})$.

\section{Gas chromatography}

Essential oil samples were analyzed on Agilent 7890A Gas Chromatography system equipped with FID detector and Agilent 5975C mass spectrometer as well as capillary flow technology which enables simultaneous analysis of the sample on both detectors. HP-5ms 5\% phenyl $95 \%$ dimethylpolysiloxane bonded phase capillary column $(30 \mathrm{~m}$ x $0.25 \mathrm{~mm}$, film thickness $0.25 \mu \mathrm{m}$ ) was used. Operating conditions were as follows: oven temperature at $60{ }^{\circ} \mathrm{C}$ for $5 \mathrm{~min}$, then increased to $80^{\circ} \mathrm{C}$ at rate of $1{ }^{\circ} \mathrm{C} / \mathrm{min}$ and held $2 \mathrm{~min}$ and at the end increased to $280{ }^{\circ} \mathrm{C}$ at rate of $5{ }^{\circ} \mathrm{C} / \mathrm{min}$ and held $5 \mathrm{~min}$; helium as carrier gas at a flow rate of $1 \mathrm{ml} /$ min; temperature of the injector $260{ }^{\circ} \mathrm{C}$ and that of the FID detector $270{ }^{\circ} \mathrm{C}$; the $\mathrm{GC}$ split ratio $1: 1.1 \mu \mathrm{l}$ of each sample was injected per GC run.

The mass spectrometry conditions were: ionization voltage $70 \mathrm{eV}$, ion source temperature $230^{\circ} \mathrm{C}$, transfer line temperature $280{ }^{\circ} \mathrm{C}$ and mass range from 50 - $500 \mathrm{Da}$. The MS was operated in scan mode.

Identification of the components present in essential oils was made by comparing mass spectra of components in essential oils with those from Nist, Wiley and Adams mass spectra libraries, by AMDIS (Automated Mass Spectral Deconvolution and Identification System) and by comparing literature and estimated Kovat's (retention) indices that were determined using mixture of homologous series of normal alkanes from $\mathrm{C}_{9}$ to $\mathrm{C}_{25}$ in hexane, under the same above mentioned conditions.

The percentage ratio of essential oils components was computed by the normalization method of the GC/FID peak areas and average values were taken into further consideration $(n=4)$.

\section{Results and discussion}

The yield of essential oils calculated on a dry mass and obtained by hydrodistillation from needles, from branches without needles and from branches with needles of $\mathrm{Pi}$ nus peuce, is given in Table 1. The obtained essential oils were transparent, light yellowish liquids with specific and strong odor.

Table 1. The yield of Pinus peuce essential oils isolated from needles, from branches without needles and from branches with needles.

\begin{tabular}{lc}
\hline \hline \multicolumn{1}{c}{ Sample } & $\begin{array}{c}\text { Yield* of essential oil } \\
(\mathrm{ml} / \mathrm{kg}) \pm \mathrm{SD}\end{array}$ \\
\hline $\begin{array}{l}\text { Pinus peuce (needles) } \\
\text { Pinus peuce (branches } \\
\text { without needles) }\end{array}$ & $4.65 \pm 1.36 \%$ \\
$\begin{array}{l}\text { Pinus peuce (branches } \\
\text { with needles) }\end{array}$ & $17.30 \pm 0.2 \%$ \\
$*(\mathrm{n}=3)$ & $7.50 \pm 0.3 \%$ \\
\hline
\end{tabular}

Table 2 shows components that were identified in the $\mathrm{Pi}$ nus peuce essential oils isolated from needles, from branches without needles and from branches with needles with their percentage amount and Kovat's retention indices. The estimated percentage values are averages of components that are present in the essential oils obtained from plant material (needles, branches without needles and branches with needles) collected from four various altitudes.

One hundred and seven components were identified in the Pinus peuce essential oils. Among them, 40 monoterpenes, 37 sesquiterpenes, 9 diterpenes and 21 other com- 
Table 2. Chemical composition of Pinus peuce essential oil from Pelister Mtn .

\begin{tabular}{|c|c|c|c|c|c|c|c|}
\hline No. & KIL & KIE & Component & $\begin{array}{c}\text { Pelister Mtn. } \\
2008 \\
(\%)-\mathrm{n}\end{array}$ & $\begin{array}{c}\text { Pelister Mtn. } \\
2009 \\
(\%)-\mathrm{n}\end{array}$ & $\begin{array}{c}\text { Pelister Mtn. } \\
2008 \\
(\%)-\mathrm{n}+\mathrm{b}\end{array}$ & $\begin{array}{l}\text { Pelister } \\
\text { Mtn. } 2008 \\
(\%)-b\end{array}$ \\
\hline & & & Monoterpene hydrocarbons & & & & \\
\hline 2 & 931 & 980.5 & $\alpha$-Thujene & - & - & 0.02 & 0.02 \\
\hline 3 & 939 & 983.7 & $\alpha$-Pinene & 12.89 & 19.72 & 23.77 & 23.34 \\
\hline 4 & 953 & 988.5 & Camphene & 2.69 & 5.03 & 3.68 & 0.69 \\
\hline 8 & 975 & 1000.3 & Sabinene & 0.05 & 0.08 & 0.02 & 0.02 \\
\hline 9 & 980 & 1002.8 & $\beta$-Pinene & 6.16 & 7.95 & 11.85 & 13.00 \\
\hline 10 & 991 & 1010.9 & Myrcene & 0.57 & 0.79 & 1.17 & 2.50 \\
\hline 12 & 1003 & 1019.8 & $\alpha$-Phellandrene & 0.14 & 0.34 & 0.16 & 0.05 \\
\hline 13 & 1007 & 1024.0 & $\Delta^{3}$-Carene & 0.33 & - & 0.58 & 0.79 \\
\hline 14 & 1018 & 1028.8 & $\alpha$-Terpinene & 0.05 & 0.10 & 0.05 & 0.02 \\
\hline 16 & 1025 & 1035.2 & $p$-Cymene & 0.22 & 0.80 & 0.05 & 0.05 \\
\hline 17 & 1031 & 1039.0 & Limonene $+\beta$-Phellandrene & 3.08 & 3.97 & 13.94 & 8.77 \\
\hline 19 & 1040 & 1064.3 & $\beta$-cis-Ocymene & 0.02 & - & - & - \\
\hline 22 & 1062 & 1064.5 & $\gamma$-Terpinene & 0.13 & 0.37 & 0.04 & 0.05 \\
\hline \multirow[t]{3}{*}{25} & 1088 & 1092.2 & Terpinolene & 0.50 & 0.65 & 0.37 & 0.24 \\
\hline & & & 14 components: & 26.83 & 39.80 & 55.70 & 49.54 \\
\hline & & & Oxigenated monoterpene & & & & \\
\hline 18 & 1033 & 1040.8 & 1,8-Cineole & 0.13 & 0.20 & - & - \\
\hline 27 & - & 1131.2 & trans-p-Menth-2-en-1-ol & 0.30 & 0.07 & 0.08 & 0.02 \\
\hline 28 & 1120 & 1136.4 & $\alpha$-Campholenal & 0.13 & 0.02 & 0.08 & 0.10 \\
\hline 29 & 1139 & 1144.8 & trans-Pinocarveol & 0.27 & 0.02 & 0.32 & 0.35 \\
\hline 31 & - & 1148.0 & Viridene & - & 0.02 & - & - \\
\hline 32 & 1143 & 1153.6 & Camphor & 0.06 & - & 0.02 & - \\
\hline 33 & 1144 & 1155.5 & trans-Verbenol & - & - & 0.03 & 0.06 \\
\hline 34 & 1160 & 1169.1 & trans-Pinocamphone & - & - & 0.03 & 0.05 \\
\hline 35 & 1162 & 1170.1 & Pinocarvone & 0.20 & 0.02 & 0.27 & 0.10 \\
\hline 36 & 1165 & 1172.5 & Borneol & 0.64 & 0.76 & 0.62 & 0.14 \\
\hline 37 & 1177 & 1181.9 & Terpinene-4-ol & 0.08 & 0.02 & 0.34 & 0.11 \\
\hline 38 & 1183 & 1189.4 & p-Cymene-8-ol & 0.08 & 0.02 & 0.09 & 0.10 \\
\hline 39 & 1189 & 1191.6 & $\alpha$-Terpineol & 0.30 & 0.29 & 0.51 & 0.45 \\
\hline 40 & 1193 & 1195.2 & Myrtenal & 0.29 & 0.16 & 0.32 & 0.35 \\
\hline 42 & 1205 & 1205.6 & trans-Piperitol & 0.19 & 0.20 & 0.02 & - \\
\hline 43 & - & 1207.1 & Verbenone & 0.04 & 0.06 & 0.10 & 0.19 \\
\hline 44 & 1212 & 1218.0 & trans-Carveol & 0.08 & 0.02 & 0.14 & 0.11 \\
\hline 45 & 1220 & 1219.9 & endo-Fenchyl acetate & 0.03 & 0.02 & 0.02 & - \\
\hline 46 & 1235 & 1237.1 & Thymol methyl ether & - & - & - & 0.02 \\
\hline 47 & 1243 & 1246.2 & Carvone & - & - & 0.05 & 0.04 \\
\hline 48 & - & 1254.6 & Piperitone & 0.02 & - & 0.02 & - \\
\hline 49 & 1256 & 1257.6 & Linalool acetate & 0.12 & 0.02 & 0.03 & 0.05 \\
\hline 51 & 1285 & 1285.6 & Bornyl acetate & 10.56 & 9.29 & 5.60 & 1.13 \\
\hline 55 & 1350 & 1347.5 & $\alpha$-Terpenyl acetate & 2.97 & 1.20 & 1.04 & 0.42 \\
\hline 58 & 1383 & 1380.9 & Geranyl acetate & 0.04 & - & - & - \\
\hline \multirow[t]{2}{*}{61} & 1401 & 1400.7 & Methyl eugenol & - & - & - & - \\
\hline & & & 26 components: & 16.45 & 12.59 & 10.39 & 3.79 \\
\hline
\end{tabular}




\begin{tabular}{|c|c|c|c|c|c|c|c|}
\hline No. & KIL & KIE & Component & $\begin{array}{c}\text { Pelister Mtn. } \\
2008 \\
(\%)-\mathrm{n}\end{array}$ & $\begin{array}{c}\text { Pelister Mtn. } \\
2009 \\
(\%)-\mathrm{n}\end{array}$ & $\begin{array}{l}\text { Pelister Mtn. } \\
2008 \\
(\%)-\mathrm{n}+\mathrm{b}\end{array}$ & $\begin{array}{c}\text { Pelister } \\
\text { Mtn. } 2008 \\
(\%)-\text { b }\end{array}$ \\
\hline & & & Sesquiterpene hydrocarbons & & & & \\
\hline 54 & 1339 & 1336.1 & $\delta$-Elemene & 0.21 & 0.11 & 0.13 & 0.18 \\
\hline 56 & 1373 & 1371.1 & $\alpha$-Ylangene & 0.02 & - & 0.08 & 0.12 \\
\hline 57 & 1376 & 1374.0 & $\alpha$-Copaene & 0.10 & 0.02 & 0.15 & 0.32 \\
\hline 59 & 1384 & 1383.3 & $\beta$-Bourbonene & 0.11 & 0.12 & 0.14 & 0.08 \\
\hline 60 & 1391 & 1389.2 & $\beta$-Elemene & 0.47 & 0.36 & 0.44 & 0.36 \\
\hline 62 & 1402 & 1403.4 & Longifolene & 0.02 & - & 0.19 & 0.22 \\
\hline 63 & 1418 & 1418.0 & trans (E)-Caryophyllene & 7.13 & 4.88 & 4.13 & 7.30 \\
\hline 64 & - & 1430.1 & $\beta$-Copaene & 0.76 & 0.40 & 0.45 & 0.57 \\
\hline 65 & 1439 & 1444.3 & Aromadendrene & 0.04 & - & 0.03 & 0.02 \\
\hline 66 & - & 1446.8 & $\gamma$-Amorphene & 0.19 & 0.15 & 0.16 & - \\
\hline 67 & 1454 & 1453.6 & $\alpha$-Hummulene & 1.59 & 0.79 & 1.00 & 1.68 \\
\hline 68 & - & 1469.1 & $\begin{array}{l}\text { Epi-bicyclosesquiphellan- } \\
\text { drene }\end{array}$ & 0.06 & 0.52 & 0.26 & 0.31 \\
\hline 70 & 1477 & 1475.8 & $\gamma$-Muurolene & 0.15 & 0.22 & 1.34 & 2.17 \\
\hline 71 & 1480 & 1481.7 & Germacrene D & 19.90 & 8.75 & 9.47 & 10.28 \\
\hline 72 & 1485 & 1493.9 & $\beta$-Selinene & 0.03 & - & 0.28 & 0.34 \\
\hline 73 & 1494 & 1496.3 & Bicyclogermacrene & 0.99 & 1.43 & 0.12 & 0.02 \\
\hline 74 & 1495 & 1497.9 & $\alpha$-Muurolene & 0.92 & 0.25 & 0.87 & 1.60 \\
\hline 75 & - & 1507.5 & trans-Cadina-1(6)4-diene & 0.02 & - & - & - \\
\hline 76 & 1513 & 1513.7 & $\gamma$-Cadinene & 0.45 & 0.39 & 1.00 & 1.88 \\
\hline 77 & 1524 & 1525.3 & $\delta$ - Cadinene & 2.71 & 1.52 & 3.06 & 4.18 \\
\hline 78 & 1532 & 1532.0 & trans-Cadina-1,4-diene & 0.06 & 0.39 & 0.12 & 0.16 \\
\hline 79 & 1538 & 1540.6 & $\alpha$ - Cadinene & 0.13 & 0.31 & 0.22 & 0.27 \\
\hline 80 & 1547 & 1546.4 & $\alpha$-Calacorene & 0.02 & 0.14 & 0.10 & 0.09 \\
\hline \multirow[t]{3}{*}{83} & - & 1571.3 & $\beta$-Calacorene & 0.02 & - & 0.07 & 0.10 \\
\hline & & & 24 components: & 36.31 & 18.62 & 22.69 & 32.26 \\
\hline & & & Oxygenated sesquiterpene & & & & \\
\hline 81 & 1564 & 1561.4 & Nerolidol-(E) & 0.18 & 0.05 & 0.18 & 0.10 \\
\hline 85 & 1574 & 1577.0 & Germacrene-4-ol & 0.10 & - & - & - \\
\hline 86 & 1576 & 1583.0 & Spathulenol & 0.32 & 0.08 & 0.46 & 0.35 \\
\hline 87 & 1581 & 1586.4 & Caryophyllene oxide & 0.57 & 0.07 & 0.70 & 1.18 \\
\hline 88 & 1590 & 1598.0 & Viridiflorol & 0.03 & - & - & - \\
\hline 89 & 1592 & 1609.0 & Longiborneol & - & - & 0.02 & 0.07 \\
\hline 90 & 1606 & 1613.0 & Humulene epoxide II & 0.12 & - & 0.12 & 0.36 \\
\hline 91 & 1627 & 1637.8 & 1-epi-Cubenol & 0.07 & 0.02 & 0.16 & 0.31 \\
\hline 92 & $\begin{array}{l}1640 \\
1641\end{array}$ & $\begin{array}{l}1644.3 \\
1647.4\end{array}$ & $\begin{array}{l}\tau \text {-Cadinol (epi- } \alpha \text {-Cadinol) }+ \\
\tau \text {-Muurolol (epi- } \alpha \text {-Muurolol) }\end{array}$ & 1.58 & 0.52 & 0.64 & 0.72 \\
\hline 93 & 1645 & 1650.1 & $\alpha$ - Muurolol (Torreyol) & 0.24 & 0.23 & 0.06 & 0.34 \\
\hline 94 & 1653 & 1657.0 & $\alpha$-Cadinol & 1.99 & 0.46 & 1.16 & 1.44 \\
\hline 95 & - & 1693.1 & Amorpha-4,9-dien-2-ol & 0.17 & 0.03 & 0.37 & 0.44 \\
\hline \multirow[t]{2}{*}{96} & 1733 & 1746.3 & Oplopanone & - & - & 0.02 & - \\
\hline & & & 13 components: & 5.37 & 1.41 & 3.89 & 5.31 \\
\hline
\end{tabular}




\begin{tabular}{|c|c|c|c|c|c|c|c|}
\hline No. & KIL & KIE & Component & $\begin{array}{c}\text { Pelister Mtn. } \\
2008 \\
(\%)-\mathrm{n}\end{array}$ & $\begin{array}{c}\text { Pelister Mtn. } \\
2009 \\
(\%)-\mathrm{n}\end{array}$ & $\begin{array}{c}\text { Pelister Mtn. } \\
2008 \\
(\%)-n+b\end{array}$ & $\begin{array}{l}\text { Pelister } \\
\text { Mtn. } 2008 \\
(\%)-b\end{array}$ \\
\hline & & & Diterpene & & & & \\
\hline 99 & 1929 & 1946.7 & Cembrene & 0.04 & - & 0.09 & 0.14 \\
\hline 100 & - & 2009.4 & Manool oxide & 0.09 & - & 0.16 & 0.18 \\
\hline 101 & 1967 & 2013.0 & Sclarene & 0.02 & 0.06 & 0.02 & 0.06 \\
\hline 102 & 2054 & 2073.7 & Abietatriene & 0.02 & 0.02 & 0.03 & 0.06 \\
\hline 103 & 2080 & 2101.4 & Abietadiene & 0.02 & - & 0.03 & 0.06 \\
\hline 104 & - & 2166.4 & Abienol & - & - & 0.14 & 0.29 \\
\hline 105 & 2220 & 2253.2 & Sclareol & - & - & 0.03 & 0.14 \\
\hline 106 & 2263 & 2296.5 & Dehydroabietal & 0.02 & - & 0.06 & 0.22 \\
\hline \multirow[t]{3}{*}{107} & 2302 & 2332.1 & Abietal & - & 0.08 & 0.03 & 0.14 \\
\hline & & & 9 components: & 0.21 & 0.18 & 0.59 & 1.23 \\
\hline & & & Other components & & & & \\
\hline 1 & 926 & 959.9 & Tricyclene & 0.02 & 0.02 & 0.21 & 0.02 \\
\hline 5 & - & 990.1 & Benzene acetaldehyde $^{t}$ & 0.16 & 0.58 & - & - \\
\hline 6 & - & 993.6 & p-Ethyl methyl benzene ${ }^{t}$ & 0.04 & 2.64 & - & - \\
\hline 7 & - & 998.1 & $1,2,5$-Trimethyl benzene ${ }^{t}$ & 0.15 & 2.23 & - & - \\
\hline 11 & 1000 & 1016.7 & n-Decane & 0.34 & 3.02 & - & - \\
\hline 15 & 1023 & 1033.3 & 1,2,4- Trimethyl benzene ${ }^{t}$ & 0.02 & 0.42 & - & - \\
\hline 20 & - & 1057.2 & 2-Phenilpropanol ${ }^{\mathrm{t}}$ & 0.12 & 0.02 & - & - \\
\hline 21 & 1057 & 1058.2 & trans-Decahydronaphtalene $e^{t}$ & 0.06 & 0.39 & - & - \\
\hline 23 & 1067 & 1084.0 & m-Tolualdehide & 0.14 & 2.30 & - & - \\
\hline 24 & 1079 & 1084.4 & p-Tolualdehide & 0.50 & 1.37 & - & - \\
\hline 26 & 1099 & 1106.8 & n-Undecane & 1.10 & 1.75 & - & - \\
\hline 30 & 1261 & 1145.0 & 2.6-Dimethylphenol ${ }^{t}$ & 0.76 & 1.50 & - & - \\
\hline 41 & 1198 & 1199.2 & Dodecane $^{t}$ & 0.25 & 0.23 & - & - \\
\hline 50 & 1261 & 1263.1 & 2-Decenal ${ }^{t}$ & 0.02 & 0.12 & - & 0.02 \\
\hline 52 & 1294 & 1296.2 & Tridecane $^{t}$ & 0.02 & - & - & - \\
\hline 53 & 1314 & 1312.5 & 2E,4E-Decadienal ${ }^{t}$ & 0.02 & 0.02 & - & - \\
\hline 69 & 1473 & 1474.5 & Dodecanol & 0.15 & 0.07 & - & - \\
\hline 82 & 1568 & 1564.8 & Dodecanoic acid ${ }^{t}$ & 0.50 & 0.06 & - & - \\
\hline 84 & 1570 & 1575.2 & Hexenyl bezoate (3-Z-) & 0.05 & 0.02 & 0.04 & - \\
\hline 97 & 1762 & 1769.9 & Benzyl benzoate & 0.05 & 0.02 & 0.02 & 0.02 \\
\hline \multirow[t]{3}{*}{98} & - & 1884.5 & Hexenyl cinnamate (3-Z-) & 0.15 & 1.23 & 0.03 & 0.02 \\
\hline & & & 21 components: & 4.55 & 16.01 & 0.30 & 0.08 \\
\hline & & & TOTAL & 89.72 & 88.61 & 93.56 & 92.21 \\
\hline
\end{tabular}

$\mathrm{n}=4$; KIL - Kovat's index literature, KIE - Kovat's index estimated, $n$ - needles, $b-$ branches without needles, $n+b-$ branches with needles, $(-)$ - not found, $\mathrm{t}$ - tentative identification, No. - ordinal number of the component according to its retention time.

ponents (aliphatic and cyclic hydrocarbons; aliphatic alcohols, aldehydes, and acids; phenols and other oxygenated benzene derivates) were identified. Analysis of the essential oils composition shows variations in the content of components that are present, probably due to the impact of weather conditions throughout the year. Seasonal variability is mostly seen in the presence of monoterpenes cam- phene and $\alpha$-terpenil acetate and sesquiterpenes $\delta$-cadinene and $\alpha$-cadinol (Table 2).

The most abundant components in the needle essential oil were monoterpenes $\alpha$-pinene $(12.89 / 19.72 \%)$, $\beta$-pinene $(6.16 / 7.95 \%)$, limonene $+\beta$-phellandrene $(3.08$ $/ 3.97 \%)$ and bornyl acetate $(9.29 / 10.56 \%)$ and sesquiterpenes trans (E)-caryophyllene $(4.88 / 7.13 \%)$ and germac- 
rene D $(8.75 / 19.90 \%)$. These components represent 54.56 $\% / 59.72 \%$ of the whole needle essential oil and are likely to determine the physico-chemical characteristics as well as chemical profile of the oils.

Dominant components in the essential oil obtained from branches with needles were the same 6 components that were found in the needle essential oils, representing $68.76 \%$ of the total amount of the oil. Among
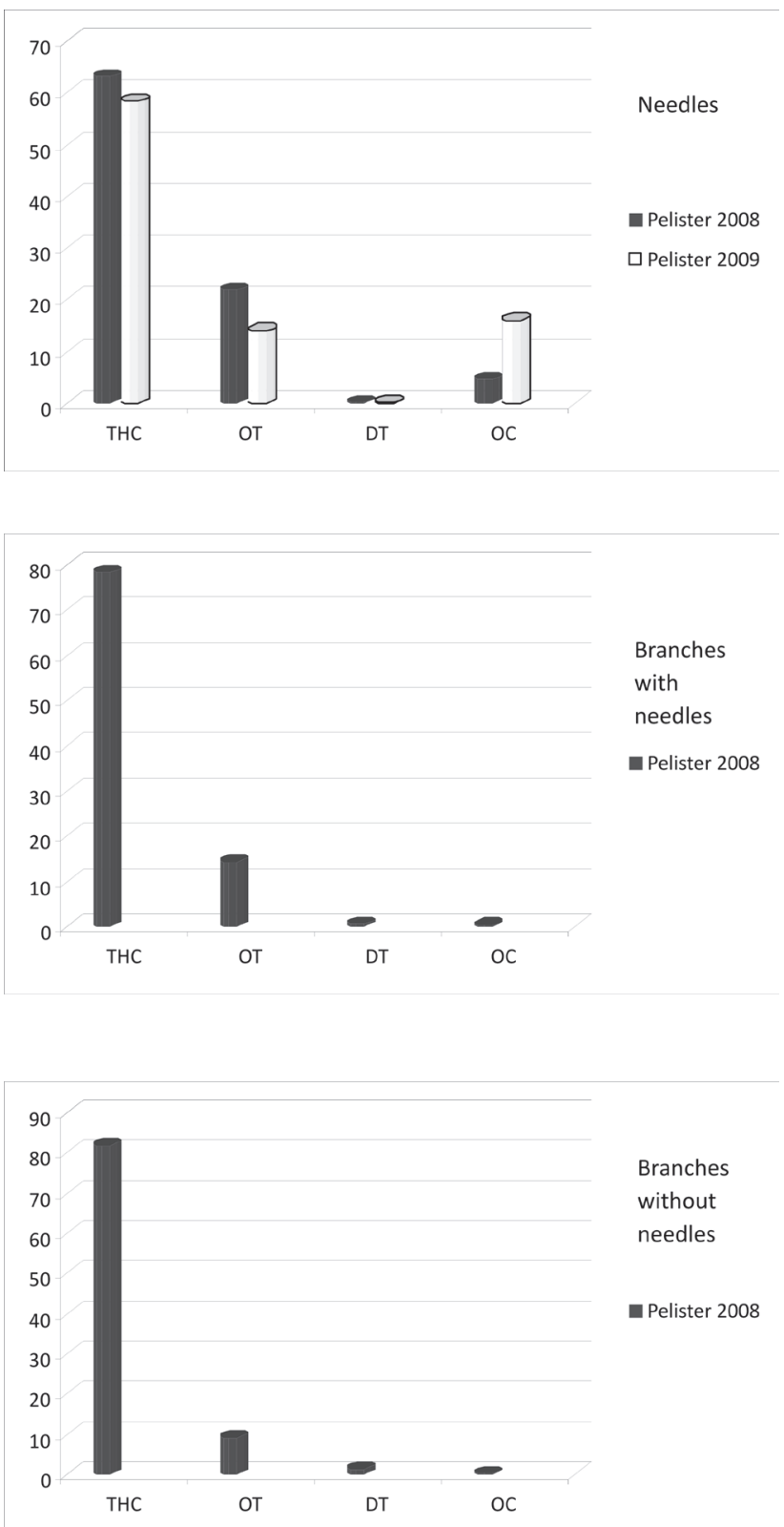

Fig. 1. Different classes of components that are present in Pinus peuce essential oils isolated from needles, from branches without needles and from branches with needles (THC - terpene hydrocarbons, OT - oxygenated terpenes, DT - diterpenes, $\mathrm{OC}$ - other components) them, $\alpha$-pinene $(23.77 \%), \beta$-pinene $(11.85 \%)$, limonene $+\beta$-phellandrene $(13.94 \%)$ were the most abundant, while germacrene D $(9.47 \%)$ and bornyl acetate $(5.60 \%)$ were present in smaller amounts.

The essential oil isolated from branches without needles contains large amount of $\alpha$-pinene (23.34\%), $\beta$-pinene $(13.00 \%)$, limonene $+\beta$-phellandrene $(8.77 \%)$, trans $(\mathrm{E})$ caryophyllene $(7.30 \%)$ and germacrene D (10.28\%), but
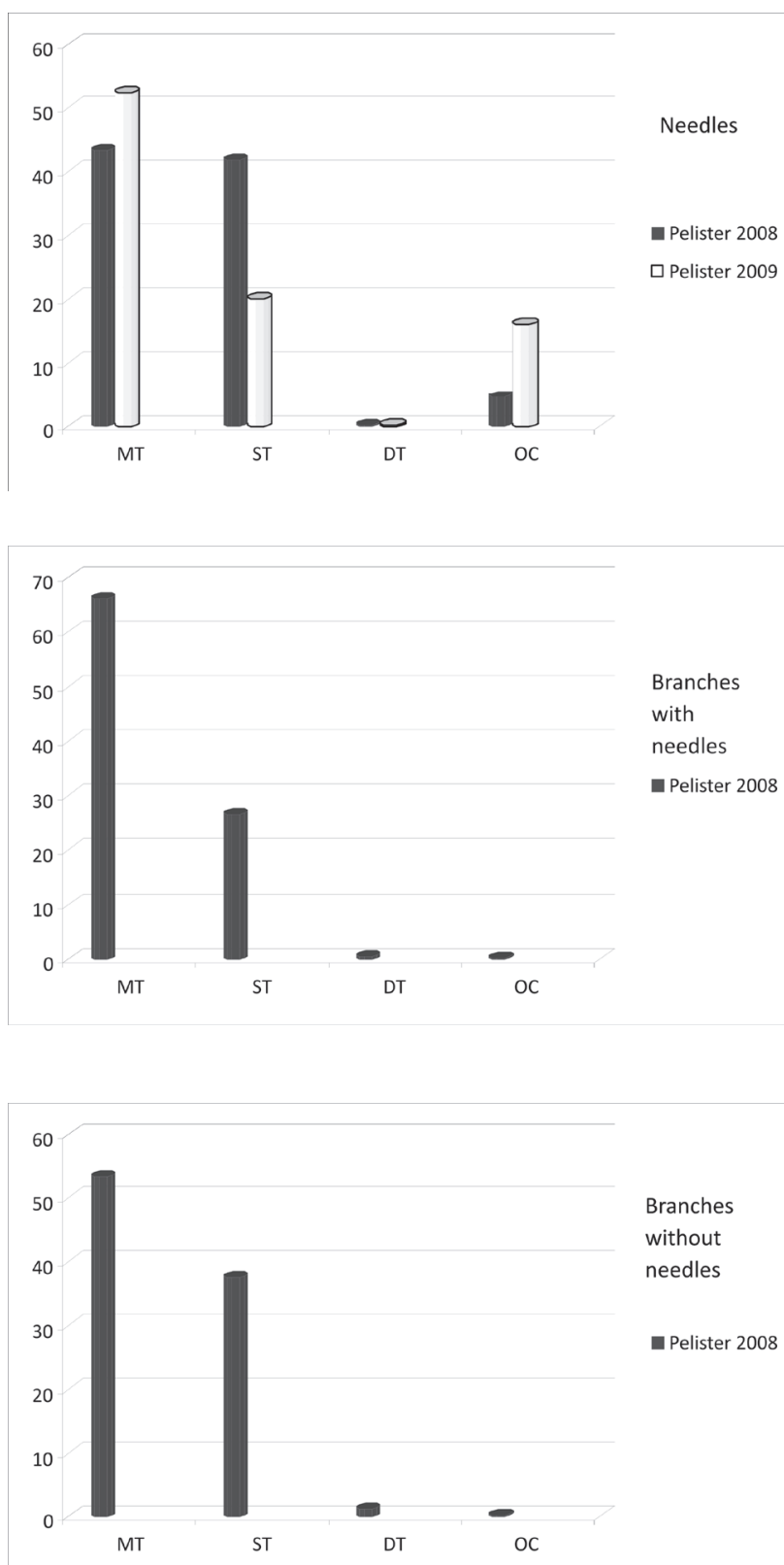

Fig. 2. Monoterpene and sesquiterpene fractions that are present in Pinus peuce essential oils isolated from needles, from branches without and from branches with needles (MT - monoterpenes, ST - sesquiterpenes, DT - diterpenes, OC - other components)

Maced. pharm. bull., $56(1,2) 13$ - 22 (2010) 
smaller amount of bornyl acetate (only $1.13 \%$ ). These components represent $63.82 \%$ of the total essential oil. It is important to notice that this essential oil contains $4.18 \%$ of $\delta$-cadinene.

Among different classes of components that are present in the needle essential oil, the major constituents were terpene hydrocarbons $(58.42 \% / 63.14 \%)$. Oxygenated terpenes were present from $14.00 \% / 21.80 \%$, other components $4.55 \% / 16.01 \%$ and diterpenes only $0.18 \% / 0.21 \%$ (Fig. 1).

The most abundant fraction among the total amount of monoterpenes and sesquiterpenes, diterpenes and other components that are present in needle essential oil were monoterpenes (43.28\%/52.39\%) (Fig. 2).

The major constituents in the essential oil obtained from branches with needles from Pinus peuce were also components that belong to terpene hydrocarbons fraction (78.39\%) and fraction of oxygenated terpenes (14.28\%) (Fig.1). The same situation was with the essential oil isolated from branches without needles which contains 81.8 $\%$ of terpene hydrocarbons fraction and $9.1 \%$ of oxygenated terpenes (Fig. 1). Diterpenes and other components were present in smaller amount $(0.59 \%$ diterpenes and $0.30 \%$ other components in the essential oil from branches with needles and $1.23 \%$ diterpenes and $0.08 \%$ other components in the essential oil isolated from branches without needles).

The most abundant fraction among the total amount of monoterpenes and sesquiterpenes, diterpenes and other components that are present in essential oil obtained from branches with needles were monoterpenes (66.09\%) (Fig. 2 ), while essential oil isolated from branches without needles contains $53.33 \%$ and $37.57 \%$ of monoterpenes and sesquiterpenes, respectively (Fig. 2).

Compared with the chemical composition of needle essential oil isolated from Pinus sylvestris (Pini sylvestris aetheroleum) and from Pinus mugo (Pini pumillionis aetheroleum) for which the European Pharmacopoeia prescribes certain limits for same components (Table 3), it is evident that the composition of needle essential oil from P. peuce is closer to the chemical composition of Pini pumillionis aetheroleum. There is no big difference in presence of $\alpha$-pinene and $\beta$-pinene between these two oils. Camphene and bornyl acetate are present in larger amount in needle essential oil from Pinus peuce while $\Delta^{3}$-carene, $\beta$-myrcene, limonene $+\beta$-phellandrene and terpinolene are present in smaller amount.

Nowdays, there are a lack of data that are relate to chemical composition of Pinus peuce essential oil. Up to now, there are only five references that are concern to the composition of the essential oils isolated from needles and branches from Pinus peuce that grows on the territory of Greece, Serbia and Montenegro (Henning, 1994; Papadopoulou, 1996; Koukos, 2000; Petrakis, 2001; Nikolic, 2008). Seventy eight components were detected, but only fifty six components were identified in the needle essential oil. $\alpha$-Pinene, camphene, $\beta$-pinene, $\beta$-phellandrene, bornyl acetate, $\beta$-caryophyllene, germacrene $\mathrm{D}$ and citronelol are declared as main components in the needle essential oil while $\alpha$-pinene, $\beta$-pinene, $\beta$-phellandrene, $\beta$-caryophyllene and citronelol are concerned as main components in the essential oil isolated from branches from $P$. peuce. Compared with essential oils isolated from $P$. peuce from Macedonia, the needle essential oil isolated from $P$. peuce from Greece contains larger amount of $\alpha$-pinene $(23.07 \%)$ and $\beta$-pinene $(22.00 \%)$ and large amount of citronellol (13.42\%), but it doesn't contain germacrene $\mathrm{D}$, while essential oil isolated from branches contains larger amount of $\beta$-phellandrene (26.93\%) and large amount of citronellol (12.48\%), smaller amount of $\alpha$-pinene $(7.38 \%)$, but it doesn't contain germacrene D and bornyl acetate. The needle essential oils isolated from $P$. peuce from Montenegro and Serbia contain larger amount of $\alpha$-pinene $(36.5 \%)$ and camphene $(8.5 \%)$, but smaller amount of bornyl acetate $(6.8 \%)$.

Table 3. Chemical composition of Pini sylvestris aetheroleum and Pini pumillionis aetheroleum (Ph. Eur 7).

\begin{tabular}{lcc}
\hline \hline \multicolumn{1}{c}{ Component } & $\begin{array}{c}\text { Pini sylvestris } \\
\text { aetheroleum }(\%)\end{array}$ & $\begin{array}{c}\text { Pini pumillionis } \\
\text { aetheroleum }(\%)\end{array}$ \\
\hline$\alpha$-Pinene & $32.0-60.0$ & $10.0-30.0$ \\
Camphene & $0.5-2.0$ & $0.0-2.0$ \\
$\beta$-Pinene & $5.0-22.0$ & $3.0-14.0$ \\
$\Delta^{3}$-Carene & $6.0-18.0$ & $10.0-20.0$ \\
$\beta$-Myrcene & $1.5-10.0$ & $3.0-12.0$ \\
Limonene & $7.0-12.0$ & $8.0-14.0$ \\
$\beta$-Phellandrene & $0.0-2.5$ & $10.0-19.0$ \\
$p$-Cymene & $0.0-2.0$ & $0.0-2.5$ \\
Terpinolene & $0.0-4.0$ & $0.0-8.0$ \\
Bornyl acetate & $1.0-4.0$ & $0.5-5.0$ \\
$\beta$-Caryophyllene & $1.0-6.0$ & $0.5-5.0$ \\
\hline
\end{tabular}

Макед. фарм. билт., 56 (1, 2) 13 - 22 (2010) 


\section{Conclusion}

The yield of needle essential oil obtained by hydrodistillation of Pinus peuce from Pelister Mtn. (Republic of Macedonia) ranged from $3.00 / 6.75 \mathrm{ml} / \mathrm{kg}$. The branches without needles contain significantly larger amounts of essential oil ( $17.30 \mathrm{ml} / \mathrm{kg})$ in terms of needles, while the values for content of essential oil in the branches with needles $(7.50 \mathrm{ml} / \mathrm{kg}$ ) were found between those obtained from needles and from the branches without needles. The obtained essential oils were transparent, light yellowish liquids with specific and strong odor.

Dominant components in the Pinus peuce essential oils obtained from needles, from branches without needles and from branches with needles were monoterpenes: $\alpha$-pinene, $\beta$-pinene, limonene $+\beta$-phellandrene and bornyl acetate and sesquiterpenes: trans (E)-caryophyllene and germacrene D. Among different classes of components in the essential oils, the major constituents were terpene hydrocarbons, both monoterpenes and sesquiterpenes, representing almost $80 \%$ of the oils.

\section{References}

Barnola, L.F., Cedeno, A., 2000. Inter-population differences in the essential oils of Pinus caribaea needles. Biochemical Systematics and Ecology 28, 923-931.

Dervendzi, V., 1992. Sovremeno lekuvanje so lekoviti bilki. Tabernakul, Skopje.

Dob, T., Berramdane, T., Chelghoum, C., 2006. Analysis of essential oil from the needles of Pinus pinaster growing in Algeria. Chemistry of Natural Compounds 41, 545-548.

Dob, T., Berramdane, T., Chelgoum, C., 2007. Essential oil composition of Pinus halepensis Mill. from three different regions of Algeria. Journal of Essential Oil Research

Dormont, L., Roques, A., Malosse, C., 1998. Cone and foliage volatiles emitted by Pinus cembra and some related conifer species. Phytochemistry 49, 1269-1277.

European Pharmacopoeia 7.0, 2010.

Grassmann, J., Hippeli, S., Vollmann, R., Elstner, E.F., 2003. Antioxidative properties of the essential oil from Pinus mugo. J. Agric. Food Chem. 51, 7576-7582.

Grassmann, J., Hippeli, S., Spitzenberger, R., Elstner, E.F., 2005. The monoterpene terpinolene from the oil of Pinus mugo L. in concert with $\alpha$-tocopherol and $\beta$-carotene effectively prevents oxidation of LDL. Phytomedicine 12, 416-423.

Gulcin, I., Buyukokuroglu, M.E., Otkay, M., Kufrevioglu, O.I., 2003. Antioxidant and analgesic activities of turpentine of Pinus nigra Arn. subsp. pallasiana (Lamb.) Holmboe. Journal of Ethnopharmacology 86, 51-58.

Guri, A., Kefalas, P., Roussis, V., 2006. Antioxidant activity of six pine species. Phytotherapy Research 20, 263-266.

Henning, P., Steinborn, A., Engewald, W., 1994. Investigation of the composition of Pinus peuce needle oil by GC-MS and GC-GC-MS. Chromatographia 38, 689-693.

Holzke, C., Hoffmann, T., Jaeger, L., Koppmann, R., Zimmer, 2006. Diurnal and seasonal variation of monoterpene and sesquiterpene emissions from Scots pine (Pinus sylvestris L.). Atmospheric Environment 40, 3174-3185.

Idzojtic, M., Kajba, D., Franjic, J., 2005. Differentiation of $F_{1}$ hybrids $P$. nigra J.F. Arnold x P. sylvestris L., P. nigra J.F. Arnold x P. densiflora Siebold et Zucc., P. nigra J.F. Arnold x $P$. thunbergiana Franco and their parental species by needle volatile composition. Biochemical Systematics and Ecology 33, 427-439.

Jerez, M., Tourino, S., Sineiro, J., Torres, J.L., Nunez, M. J., 2007. Procyanidins from pine bark: Relationships between structure, composition and antiradical activity. Food Chemistry 104, 518-527.

Jerez, M., Selga, A., Sineiro, J., Torres, J.L., Nunez, M. J., 2007. A comparison between bark extracts from Pinus pinaster and Pinus radiate: Antioxidant activity and procyanidin composition. Food Chemistry 100, 439-444.

Judzentiene, A., Slizyte, J., Stikliene, A., Kupcinskiene, E., 2006. Characteristics of essential oil composition in the needles of young Scots pine (Pinus sylvestris L.) stands growing along an aerial ammonia gradient. Chemija 17 (4), 67-73.

Kainulainen, P., Holopainen, J.K., 2002. Concentrations of secondary compounds in Scots pine needles at different stages of decomposition. Soil Biology and Biochemistry 34, $37-42$.

Kamin, W., Kieser, M., 2007. Pinimethol ointment in patients suffering from upper respiratory tract infections - A postmarketing observational study. Phytomedicine 14, 787-791.

Kupcinskiene, E., Stikliene, A., Judzentiene, A., 2008. The essential oil qualitative and quantitative composition in the needles of Pinus sylvestris L. growing along industrial traces. Environmental Pollution 20, 1-11.

Limei, Y., Zhao, M., Wang, J.S., Cui, C., Yang, B., Jiang, Y., Zhao, Q., 2008. Antioxidant, immunomodulatory and antibreast cancer activities of phenolic extracts from pine (Pinus massoniana Lamb.) bark. Innovative Food Science and Emerging Technologies 9, 122-128.

Maciag, A., Milakovic, D., Christensen, H.H., Antolovic, V., Kalemba, D., 2007. Essential oil composition and plantinsect relations in scots pine (Pinus sylvestris L.). Food Chemistry and Biotechnology 1008, 71-95.

Menkovic, N.R., Ristic, M.S., Samardzic, Z.J., Kovacevic, N.N., Tasic, S.R., 1993. Investigations of relic Pinus species . II. The essential oil of Pinus heldreichii. ISHS Acta Horticulturae. 344.

Micevski, K., 1985. Flora na SR Makedonija.

Naydenov, K., Tremblay, F., Fenton, N., Alexandrov, A., 2006. Strucure of Pinus nigra Arn. populations in Bulgaria revealed by chloroplast microsatellites and terpenes analysis: Provanance tests. Biochemical Systematics and Ecology 34, 562-574.

Nikolic, B., Ristic, M., Bojovic, S., Marin, P.D., 2007. Variability of the needle essential oils of Pinus heldreichii from different populations in Montenegro and Serbia. Chemistry and Biodiversity 4, 905-916.

Oluwadayo Sonibare, O., Olakunle, K., 2008. Chemical composition and antibacterial activity of the essential oil of Pinus caribaea from Nigeria. African Journal of Biotechnology 7 (14), 2462-2464.

Pagula, F., Baeckstrom, P., 2006. Studies on essential oil-bearing plants from mozambique: Part II. volatile leaf oil of needles of Pinus elliotti Engelm. and Pinus taeda L. Journal of Essential Oil Research 18 (1), 32-34.

Petrakis, P.V., Tsitsimpikou, C., Tzakou, O., Couladis, M., Vagias, C., Roussis, V., 2001. Needle volatiles from five Pinus species growing in Greece. Flavour and Fragrance Journal 16 (4), 249-252. 
Pinelo, M., Rubilar, M., Sineiro, J., Nunez, M. J., 2004. Extraction of antioxidant phenolics from almond hulls (Prunus amygdalus) and pine sawdust (Pinus pinaster). Food Chemistry 85, 267-273.

Roussis, V., Petracis, P.V., Ortiz, A., Mazomenos, B.E., 1994. Volatile constituents of needles of five Pinus species grown in Greece. Phytochemistry 39 (2), 357-361.

Sacchetti, G., Maietti, S., Muzzoli, M., Scaglianti, M., Manfredini, S., Radice, M., Bruni, R., 2005. Comparative evaluation of 11 essential oils of different origin as functional antioxidants, antiradicals and antimicrobials in foods. Food Chemistry 91, 621-632.

Semiz, G., Heijari, J., Isik, K., Holopainen, J.K., 2007. Variation in needle terpenoids among Pinus sylvestris L. (Pinaceae) provenances in Turkey. Biochemical Systematics and Ecology 35, 652-661.

Stevanovic, T., Garneau, F.X., Jean, F.I., Gagnon, H., Vilotic, D., Petrovic, S., Ruzic, N., Pichette, A., 1998. The essential oil composition of Pinus mugo Turra from Serbia. Wiley InterScience Research Article.

Tognolini, M., Barocelli, E., Ballabeni, V., Bruni, R., Bianchi, A., Chiavarini, M., Impicciatore, M., 2006. Comparative screening ofplant essential oils: Phenylpropanoid moiety as basic core for antiplatelet activity. Life Science 78, 14191432.

Ucar, G., Balaban, M., 2004. Volatile needle extractives of Anatolian black pine varieties: $P$. nigra subsp. pallasiana var. pallasiana and var. pyramidata. Biochemical Systematics and Ecology 32, 983-992.

Ustun, O., Sezik, E., Kurkcuoglu, M., Baser, K.H.C., 2006. Study of the essential oil composition of Pinus sylvestris from Turkey. Khimiya Prirodnykh Soedinenii 1, 22-25.

Youg-Suk, K., Dong-Hwa, Sh., 2005. Volatile components and antibacterial effects of pine needle (Pinus densiflora $\mathrm{S}$. and Z.) extracts. Food Microbiology 22, 37-45.

\title{
Резиме
}

\section{Хемиски состав на етерично масло од молика (Pinus peuce Griseb., Pinaceae) од Пелистер, Р. Македонија}

\author{
Марија Карапанџова*, Ѓоше Стефков, Светлана Кулеванова
}

\begin{abstract}
Институт за Фармакогнозија, Фармацевтски факултет, Универзитет “Св. Кирил и Методиј”, Скопје, Р. Македонија
\end{abstract}

Клучни зборови: Pinus peuce, македонски бор, хемиски состав на етерично масло, GC/FID/MS, Национален парк Пелистер, locus classicus, Р. Македонија.

Анализата на хемиски состав на етерични масла добиени со дестилација со водена пареа од иглички, од гранки без иглички и од гранки со иглички од молика (Рinus реисе Griseb., Pinaceae) собрана на Пелистер (P. Македонија) е направена со GC/FID/ MS. Вкупно се идентификувани сто седум компоненти (40 монотерпени, 37 сесквитерпени, 9 дитерпени и 21 други соединенија - алифатични и циклични јаглеводороди; алифатични алкохоли, алдехиди и киселини; феноли и други оксидирани деривати на бензенот). Најзастапени компоненти се компонетите од класата на терпенските јаглеводороди, вклучувајќи ги монотерпените $\alpha$-пинен, $\beta$-пинен, лимонен $+\beta$-феландрен и борнил ацетат и сесквитерпените trans (E)-кариофилен и гермакрен D. 